\title{
Business development activities at academic institutions as related to the education, training, and career development of the next generation of scientists and professionals
}

\section{Kamran Mobarhan}

Kamran S. Mobarhan, "Business development activities at academic institutions as related to the education, training, and career development of the next generation of scientists and professionals," Proc. SPIE 9665, Tenth International Topical Meeting on Education and Training in Optics and Photonics, 96650D (3 June 2007); doi: 10.1117/12.2207511 


\title{
Business Development Activities at Academic Institutions as Related to the Education, Training, and Career Development of the Next Generation of Scientists and Professionals.
}

\author{
Kamran S. Mobarhan, Ph.D. \\ CEO and Director of Business Development, L2M Academy, Inc., \\ San Jose, California, U.S.A., email: kmobarhan@hotmail.com
}

\begin{abstract}
Every year large sums of tax payers money are used to fund scientific research at various universities. The result is outstanding new discoveries which are published in scientific journals. However, more often than not, once the funding for these research programs end, the results of these new discoveries are buried deep within old issues of technical journals which are archived in university libraries and are consequently forgotten. Ideally, these scientific discoveries and technological advances generated at our academic institutions should lead to the creation of new jobs for our graduating students and emerging scientists and professionals. In this fashion the students who worked hard to produce these new discoveries and technological advances, can continue with their good work at companies that they helped launch and establish. This article explores some of the issues related to new business development activities at academic institutions. Included is a discussion of possible ways of helping graduating students create jobs for themselves, and for their fellow students, through creation of new companies which are based on the work that they did during their course of university studies.
\end{abstract}

\section{Introduction}

Every year thousands of students graduate from our academic institutions and start looking for jobs. Even though this is a good course of action for most graduating students, it is not the appropriate thing for a considerable portion of students. This group of students would benefit more if they do not look for jobs but rather create new jobs for themselves through establishing of new businesses based on work they did at the university and ideas they developed through their course of education.

\section{Case Studies}

The following are stories about students who were going through college and graduate school at one of the top universities in the United States during the 1990s. In these stories the names have been altered for privacy reasons. These are stories about students who had an entrepreneurial spirit and would had benefited from being encouraged and helped to create new jobs for themselves rather than looking for jobs upon graduation.

Kelly went through college and graduate school supporting herself through tutoring and part time teaching jobs. During her undergraduate years, she worked about fifteen hours per week as an academic tutor for the athletic department of her university. Her job was tutoring student athletes in such fields as mathematics,

Tenth International Topical Meeting on Education and Training in Optics and Photonics, edited by Marc Nantel, Proc. of SPIE Vol. 9665, 96650D - @ 2007 SPIE, OSA, IEEE, ICO 
physics, and engineering courses. In addition she had a number of regular clients from the local high schools. During her graduate years she worked as an engineering teaching assistant. She was told by numerous people to be an excellent teacher. This included her students, their parents, many college professors, and high school teachers. She was a person who was truly dedicated to the important profession of educating young people and she very much enjoyed and took great pride in the work she did.

Upon graduation Kelly could have gone to create and launch a tutoring and teaching business. In this way she could have gone on to provide excellent service to the students of her community, do what she liked best, and could have provided a number of new tutoring and teaching jobs for many of her classmates. Throughout the years her business could have become a national franchise with new employment opportunities for thousands of people. But this did not happen.

Alberto was a graduate student in the 1990s at a research center at one of our most prominent universities. This research center was dedicated to research and development work in the area of advanced semiconductor technologies. During the course of his doctorate research work Alberto designed and built a machine for the specific purpose of packaging a new type of high power semiconductor lasers which at the time were at the cutting edge of optoelectronic technology. He also developed a novel technique of bonding and packaging of these semiconductor based optoelectronic devices. He integrated this new device packaging technology into the machine he had designed and built. As a result of this work numerous papers were published in various prestigious scientific journals. However, no new jobs were created for either Alberto or anyone else.

Various aspects of the technology which Alberto developed, including the design of his new high power laser diode packaging machine could have been patented. This was not done. With proper support and guidance Alberto could have gone on to productize and bring to market his optoelectronic packaging machine and the novel high power laser diode packaging technology which he had developed. This could have effectively been accomplished through the creation of a new applied optoelectronic technology firm. In this way a new company could have been established and new jobs could have been created for Alberto as well as for many of the next generation of students graduating from the same research center from which Alberto graduated. But none of this happened.

Working in a similar research field as Alberto was Maribel. Like Alberto, Maribel was also working on research projects funded by prominent government research agencies. Like the work of Alberto, the work of Maribel also had a highly applied nature. Her work was related to test, measurement, and characterization of a new type of semiconductor based optoelectronic devices.

As part of her work Maribel designed and developed a series of new test and measurement techniques. Her work included the development of a series of new highly industrialized application specific analysis software for automated test and characterization of new optoelectronic devices used in the field of Dense Wavelength Division Multiplexing (DWDM) technologies. DWDM is the technology which is the foundation of the modern fiber-optic based telecommunication industries. Maribel could have gone on to create and launch a new laboratory instrumentation and scientific analysis software company which could have had the potential of becoming a multi-million dollar business. But this did not happen.

Ivan, an engineering student at a large highly ranked university during the 1990s, supported himself throughout his university years by writing papers for professors at his university, creating conference presentations for them, and doing a variety of graphics design works for them such as preparing exceptionally interesting technical diagrams used in demonstrating the results of their research work. He occasionally offered his services to professors in the form of ghost writing book chapters for them. In addition to these, since he was an experienced photographer with artistic talents, he used to have photographs taken of the experimental setups used in the laboratories of engineering and physics professors. These photos were then used in various magazines, publications, and conference presentations by his clients. After graduating, Ivan could have gone on to create a new technical writing and graphics design business which working with various advertising and publishing firms could have resulted in the creation of a number of new jobs for the community. But this did not happen. 


\section{What to do}

The students whose stories were narrated above ended up getting relatively good jobs following their graduation. However, they could have gone on to launch new businesses and could have created many new employment opportunities for themselves and for others. This did not happen. These are opportunities lost and we should ask ourselves why this did not happen and what could be done to prevent similar failures from happening in the future.

1) We need more professors and educators who are fully dedicated to the important task of educating and training of our next generation of professionals. Most professors working at our top research oriented universities are so busy with doing research that they do not have much time to focus primarily on the education of students. These professors are constantly under tremendous amount of pressure to generate new sources of funding for the university each year. Their measure of success is primarily the amount of financial funding they generate each year for the university and the number of technical papers they publish. They are not incentivised to worry about their students being able to start and establish new businesses.

When I was attending university as a graduate student one of my professors, who is now a world famous scientist, stood in front of a classroom full of students and said: "As a scientist, teaching is a burden for me." As a student attending that class I was very hurt and offended by this comment. We need to hire more professors who believe that teaching and the profession of education is an honour and a social privilege. It is important to have at least a portion of our academic faculty to be men and women who are primarily dedicated to the important task of educating our next generation of professionals and helping our graduating students create new companies and new jobs.

It is best to hire professors who have a diverse multi-faceted background and skill set covering both academic scientific knowledge as well as industrial and business world experiences. An educator who has a doctorate degree in his or her field of expertise and some years of academic scientific research experience can add some value to the education of our students. However, an educator who has this same qualifications but in addition has years of experience working in the industry and also has product management, marketing, and business development experiences can add much more value when it comes to educating our future professionals and helping them launch new businesses thus creating many new jobs.

2) A significant percentage of our university students have entrepreneurial spirit and ambitions with great potential to start their own companies soon after graduation or even while at college. This select group of students need to be encouraged to create jobs for themselves, and for their fellow classmates, instead of looking for jobs elsewhere.

A young person in his or her early twenties may not readily be aware that such options exist, or if they do then they may not have the confidence or access to the means to make such dreams come true. They need to be supported in achieving their entrepreneurial ambitions. The students whose stories were told earlier in this article are among such individuals but at the time they did not have access to proper business guidance and support in order to start their own companies.

3) We need to establish New Business Development units at our universities. The mission of these New Business Development departments should be to provide guidance and support to young undergraduate and graduate students who have the talent to be our future business leaders and who wish to start their own new companies while still in college or soon upon graduation.

Major universities typically have dedicated scientific research centers that are the focal point of scientific research activity within each area of technical specialty. Usually dozens of graduate and undergraduate students work at such research centers along with a number of engineers, scientists, technicians, and several professors. The head of the center is a scientific director who is a senior professor in charge of leading and managing the research activities of the whole center and is responsible for generating the necessary annual financial funding for the ongoing operations of the research center. 
What typically is missing within such research centers is the position of Director of Business Development. Someone whose mission would be to productize and market the great technologies that are created at the research center. This person would be responsible for assisting those students of the center who are interested create new companies based on the research work they have performed at the center. If during the 1990s there existed a Director of Business Development at the particular research center where Alberto and Maribel worked, then it could have been possible that these two students would have been encouraged and enabled to create their own new successful companies.

Many universities currently have Technology Transfer departments which essentially market the research results of the professors to the industry primarily in the form of licensing the patent rights of the new technologies developed by the university faculty. However, in addition to these Technology Transfer departments there should exist New Business Development departments which would be fully dedicated to helping students launch new businesses, ideally based on the work done by them during their course of studies.

Why not help and support students, and provide guidance to them, so that they can begin establishing a new company with a viable business plan while still going through college. By the time such individuals graduate from university they potentially could be in a position to hire their fellow classmates. Also because they have created a mission and a professional goal for themselves, they will be able to tailor their university course of studies in a more optimum fashion.

They can choose and tailor their courses in such manner that by the end of four years they would be well equipped with the right tools in order to succeed in the business venture they have already embarked upon, as opposed to going through a standard four year college program and upon graduation wondering what to do with their education and what type of job to get. Instead of looking for job opportunities they will be able to offer job opportunities to others.

4) We need to provide to interested students incubator facilities and assistance in applying for both government as well as private sector funding in order to start their new businesses. This effort must be led and directed by the New Business Development department with heavy participation of the interested academic professors. Those university professors who choose to participate in this type of activity should be rewarded for their contributions and successes. The primary measure of success of the New Business Development department, and of the professors who are working with this department, should be how many new jobs were created by the students of the university soon upon their graduation.

Under this scenario it would not have been considered sufficient that the students whose stories were mentioned earlier in this article, all successfully graduated with advanced technical degrees and found jobs. Success could only have been claimed if all of these stories would have ended with successful new businesses and companies having been created. Ultimate success would have been if today the companies created by these students were thriving prosperous businesses employing thousands of individuals.

5) A significant portion of the scientific research done in our universities is funded by government research agencies such as the Defense Advanced Research Projects Agency (DARPA). The result is outstanding new discoveries which are published in scientific journals. However, more often than not, once the funding for these research programs end, the results of these new discoveries are buried deep within old issues of technical journals which are archived in university libraries and are consequently forgotten. Ideally, these scientific discoveries and technological advances generated at our academic institutions, and paid for by tax payers, should lead to the creation of new jobs for our graduating students and emerging scientists and professionals. In this fashion the students who worked hard to produce these new discoveries and technological advances, can continue with their good work at companies that they helped launch and establish. 
In order to achieve the above mentioned objectives it is highly beneficial that government research agencies, in addition to the research programs they typically manage, also have a series of programs dedicated to productization of the research results produced through their currently funded research programs.

Such industrialization and business development programs should be managed by government agency program managers whose focus would be on closing the relatively wide gap between universities generating novel ideas and the introduction of these ideas to market in the form of well developed technologies and products. In doing so a mechanism will be created through which many new companies are created based on scientific research performed at the research centers of our academic institutions.

Program managers and directors working at our government research agencies are in a position to facilitate this and thus contribute in a significant way to not just providing the funding necessary for the training of our next generation of scientists and engineers but also contribute to, and positively influence, their professional advancement. This can result in the creation of a series of new industries and businesses leading to the generation of numerous new employment opportunities for our graduating students.

\section{Summary}

This article is about how to plant the seeds of future industries through encouraging and supporting new business development activities at our universities.

Many of the students studying at our academic institutions have entrepreneurial spirit and possess innovative applied technological ideas. These students should be encouraged and be provided with proper guidance and support. They should be enabled so that they are in a position to create new jobs for themselves and for their fellow students instead of looking for jobs after they graduate.

The way to do this is through hiring more professors, educators, and administrators, who are truly dedicated to the task of educating our young minds and are in a position to help and support students with their new business development ideas and efforts.

We should have at our academic institutions dedicated business development directors whose primary function is to provide guidance and support to students in regard to starting new companies. These business development directors should have the responsibility of facilitating the success of the students in creating new job opportunities.

\section{About the Author}

Kamran Mobarhan is an international businessman and free-lance writer living between San Jose, California and Mexico City, Mexico. He is the co-founder and CEO of a newly established company called L2M Academy, Inc. which is a business dedicated to the education and career development efforts of young people. Kamran has BS, MS, and Ph.D. degrees in the field of Electrical Engineering, all from Northwestern University. He has many years of experience in technology marketing, business development, product management, and engineering at high-tech companies and research centers. He is the author of numerous technical papers, conference presentations, and articles. He can be reached at kmobarhan@ @otmail.com 